\title{
Metacognitive Awareness of Listening Strategies among Science Pre-University Students
}

\author{
Nur Anneliza Abd Latip ${ }^{1}$, Suyansah Swanto, ${ }^{2,}$, Wardatul Akmam Din ${ }^{1}$ \\ ${ }^{1}$ Preparatory Centre for Science and Technology, University Malaysia Sabah, Malaysia \\ ${ }^{2}$ Faculty of Psychology and Education, University Malaysia Sabah, Malaysia
}

Received July 7, 2020; Revised August 18, 2020; Accepted September 11, 2020

\section{Cite This Paper in the following Citation Styles}

(a): [1] Nur Anneliza Abd Latip, Suyansah Swanto, Wardatul Akmam Din , "Metacognitive Awareness of Listening Strategies among Science Pre-University Students," Universal Journal of Educational Research, Vol. 8, No. 11, pp. 5265 - 5270, 2020. DOI: 10.13189/ujer.2020.0801127.

(b): Nur Anneliza Abd Latip, Suyansah Swanto, Wardatul Akmam Din (2020). Metacognitive Awareness of Listening Strategies among Science Pre-University Students. Universal Journal of Educational Research, 8(11), 5265 - 5270. DOI: 10.13189/ujer.2020. 0801127.

Copyright $\subseteq 2020$ by authors, all rights reserved. Authors agree that this article remains permanently open access under the terms of the Creative Commons Attribution License 4.0 International License

\begin{abstract}
Listening is one of the fundamental skills to acquire knowledge in an academic setting. Employing appropriate listening strategies can improve focus and stimulate listening comprehension. Looking into the cognitive process from the perspective of metacognitive awareness during listening activity could enhance their performance in listening test. Despite that, listening skill in learning English as a second language (ESL) is often overlooked and the least practiced compared to other skills. There is a need to address the dearth of focus and research on approaching listening skills to improve the students' proficiency. The present study aims to investigate the relationship between Metacognitive Awareness of Listening Strategies (MALS) and listening achievement. To attain this, one hundred and sixty-nine science foundation students answered Metacognitive Awareness of Listening Questionnaire (MALQ) and took Malaysian University English Test (MUET). The result of the analysis shows that there was a significant relationship between students' MALS and listening performance. Subsequently, listening performance marks were found to be positively related to person knowledge strategies and inversely to mental translation strategies. Triangulation data was also done where 20 students were involved in further discussion of strategies that they have applied. The study also recommends looking into the practice of listening in Malaysia, particularly in pre-university level.
\end{abstract}

Keywords Listening Skill, Metacognitive Awareness of Listening Strategies, Malaysian University English Test

\section{Introduction}

Listening skill is the initial step in using the language and using it effectively can ensure academic success in university setting [1,2]. Listening comprehension problems were accentuated by many experts to improve learning. However, listening comprehension is the least explicit language skill, seldom tackle and widely acknowledged as a neglected skill due to insufficient pedagogical development, teacher training, absence of empirical approach to the process and the nature of listening to itself which is a cognitive process and therefore difficult to observe [4-8].

\subsection{Listening Skill in Malaysia}

Listening skill in Malaysian classroom is not given the treatment or status in most language learning. In secondary school, listening skill is the least practiced skill and receives significantly less attention compared to writing and reading making it unsatisfactorily acquired by the students $[9,10]$. Furthermore, listening test was not appropriately introduced to the lower form students in secondary school until 2014 where Penilaian Tingkatan Tiga (PT3) was introduced to replace the Penilaian Menengah Rendah (PMR) examination [11]. Meanwhile, in the upper form, the students take Sijil Pelajaran 
Malaysia (SPM) examination where the English component does not test on listening skill. Hence, the only window for listening skill is in MUET, only because it is tested as a detached skill [9]. The inadequate experience in this skill may have an impact on their pre-university level and become prominent when they enter degree study.

MUET is firstly introduced in 1999 to fill the language proficiency gaps between secondary and tertiary level, is now a commonly used benchmark in determining one's competence in English for the purpose of admission into tertiary institutions [12,13]. Analysis of MUET scores showed that listening test has the lowest achievement compared to others [14]. Meanwhile, overall analysis by the Malaysian Examinations Council in 2017 and 2018 shows that listening result in July, March and November has the highest Band 1 achievement compared to other skills $[15,16]$.

ESL learners in Malaysian university achieved better in the listening test after their level of MALS was raised [18]. It is vital to investigate the process of listening involved and in particular how strategies can be used to manage comprehension efforts. For that reason, this study is concerned to focus on the relationship between MALS and listening proficiency among science pre-university students in Universiti Malaysia Sabah (UMS).

\subsection{Metacognitive Awareness of Listening Strategies (MALS)}

Metacognition refers to consciousness on our mental processes, and learners who take conscious steps to understand that process tend to be the most successful learners $[19,20,22]$. Moreover, metacognition is a form of cognition and a high-level thinking process that involves active control over cognitive processes and is considered as the seventh sense [21,22]. Metacognitive awareness refers broadly to these manifestations revealing a person's consciousness of personal thoughts and conscious [24]. Metacognitive awareness of listening strategies is the learners' knowledge about strategy use in listening and MALQ is the tool to investigate this knowledge.

\subsection{Problem Statement}

Research in ESL learners' listening comprehension performance is still limited. In listening assessment, most of the orientation focused on outcome oriented rather than the process [17]. Language teacher and learners need to clearly grasp the listening processes and how strategies can be used to enhance comprehension. Learners should be aware of the strategies that can be used to improve listening ability. Compared to other language skills, listening receives the least systematic treatment with a lack of instructional materials [24]. In reading, teacher can use strategies and direct learners' attention to comprehension scaffolding. While in writing, teachers can build the process of writing from brainstorming, drafting, and revising. Listening lessons should also offer and focus on such opportunities.

Many of the listening activities only involve listening to the input repetitively and without any interruption, and this is far from real-life situation [24]. In the MUET listening test, it involves listening to a selective type of audio twice in a short duration which may be inadequate to grasp the process. The result, learners are constantly trying to understand what they hear but never get a chance to self-evaluate and learn how to deal with the process. A possible reason for this is that many instructors are unsure of how to approach listening in a more principled manner [24].

MALS could be powerful variables to investigate ESL learners' listening performance. Language instructors in university need to view from a metacognitive perspective, assist the students to think and self-reflect the process [26]. In Malaysian universities, there is apparently lacking in learning appropriate strategies in metacognitive perspectives. This research is focusing on MALS in stimulating the students' listening comprehension. It is believed that metacognitive awareness helps listeners think about the listening process, manage their strategies, tackle the problems and consequently improved listening achievement $[25,27]$. Limited research has been made to examine these variables related to listening achievement of pre-university students in Malaysia. Hence, this study attempts to investigate the role of MALS and listening performance.

\subsection{Objectives}

More research is necessary to study the listening strategies from the perspective of metacognitive awareness and listening achievement among pre-university students in Malaysia. Hence, this study seeks to:

i. identify the relationship between MALS and listening achievement among science pre-university students in Malaysia

\section{Materials and Method}

In view of the research questions and purposes, this study conducted through multimethod research design composed of mixing both types of data; quantitative and qualitative, from different approaches or methods used in different styles, combined in the same research project parallel or sequence but are not integrated until inferences are being made [28-30] This study involves multiple operationalization where different methods to measure something are applied, and then these methods had to be converged. This is in line with the concept of triangulation, coined by Denzin in 1978.

\subsection{Participants}

One hundred and sixty-nine students enrolled in 
Science Foundation programme in 2018/2019 session were chosen to participate in this study. In addition, 20 students were interviewed for data triangulation.

\subsection{Instruments}

\subsubsection{Metacognitive Awareness of Listening Questionnaire (MALQ)}

MALQ contains 19 items and each item is rated on a 6-point Likert scale ranging from 1 (strongly disagree) to 6 (strongly agree) without a neutral point. It has five subscales which are problem solving (6 items), planning evaluation (5 items), mental translation (3 items), person knowledge ( 3 items) and directed attention ( 2 items). The reliability coefficients are $0.70,0.71,0.79,0.65$ and 0.63 , respectively.

\subsubsection{Malaysian University English Test (MUET)}

MUET is a test of English language proficiency, largely for university general requirement. It comprises of four components which are Listening, Speaking, Writing, and Reading. The aggregated score is interpreted as band 1 to 6. Score of Band 1 represents "extremely limited user" and this ranges to score of band 6 representing "very good user”. MUET Listening (800/1) March 2019 examination will be used in this exam. The exam consists of 45 questions of three parts: Part I, Part II and Part III. Parts I and II have one listening text each. Part III has three short texts. Candidates must answer twenty questions in the form of short answers, information transfer and multiple choice of questions. The duration of the exam is 30 minutes. Full mark for this exam is 45 marks.

\subsubsection{Semi Structured Interview}

A set of similar questions were asked to each participant. The questions are taken from the questionnaire. The researcher also combines it with a set of open questions which may prompt discussion to explore further responses or themes.

\subsection{Data Analysis}

Data analysis was conducted using the Statistical Package for Social Sciences 21 (SPSS). For measuring the degree of association between two quantitative variables, Spearman's coefficient of correlation is used in the parametric test. Shapiro-Wilk output shows that the value of MUET is 0.000 which depicts positively skewed data. Thus, suggesting strong evidence of non-normality. Since the distribution is not normally distributed, the non-parametric tests were used.

\section{Results}

\subsection{Data Analysis}

\subsubsection{Descriptive analysis}

Table 1. Descriptive analysis for MALQ and MUET

\begin{tabular}{|c|c|c|c|c|c|}
\hline $\begin{array}{c}\text { Descriptive } \\
\text { analysis }\end{array}$ & Mean & Median & $\begin{array}{c}\text { Standard } \\
\text { deviation }\end{array}$ & $\begin{array}{c}\text { Min. } \\
\text { value }\end{array}$ & $\begin{array}{c}\text { Max. } \\
\text { value }\end{array}$ \\
\hline MALQ & 4.60 & 4.60 & 0.46 & 3.38 & 5.89 \\
\hline MUET & 31.85 & 32.00 & 5.55 & 14.00 & 45.00 \\
\hline
\end{tabular}

Table 1 shows the descriptive analysis for MALQ and MUET. The average (mean) and middle set (median) of the overall score is 4.60. This suggests that the participants were partially agreed with the statements in the questionnaire. The standard deviation of 0.46 shows that there was low variability in overall metacognitive awareness among the participants. Table 1 also shows the mean is 31.85, which indicates that the participants averagely scored 31 out of a maximum 45 in the MUET listening test, indicative of their intermediate (Band 4) listening proficiency. The middle set of the number (median) is 32 and the sizeable standard deviation of 5.55, which depicts medium variability in listening proficiency among them. Moreover, the lowest mark obtained is 14 marks and the highest is 45 marks. This shows a listening achievement gap among the students.

\subsubsection{Quantitative result}

Table 2 shows the findings obtained from performing Spearman correlations between the total scores of MALQ and MUET marks. Findings of data analysis in terms of Spearman correlation show that there was a significant correlation of 0.346 between the learners' MALS and their listening achievement of MUET. Subsequently, results show that there is a significant positive correlation of 0.507 between students' person knowledge and their MUET marks. This indicates that students with higher marks perceived listening as less difficult and less challenging compared to the other three language skills. They also felt less nervous when answering listening questions. Further, there is a negative correlation of -0.308 between students Mental Translation and their MUET marks. This shows that students with higher marks tend to not translate when listening.

Table 2. Spearman correlations between the total scores of MALS and MUET

\begin{tabular}{|c|c|c|c|c|c|c|}
\hline $\begin{array}{c}\text { Spearman's Rho / } \\
\text { Correlation Coefficient }\end{array}$ & $\begin{array}{c}\text { Problem } \\
\text { Solving }\end{array}$ & $\begin{array}{c}\text { Planning and } \\
\text { Evaluation }\end{array}$ & $\begin{array}{c}\text { Mental } \\
\text { Translation }\end{array}$ & $\begin{array}{c}\text { Person } \\
\text { Knowledge }\end{array}$ & $\begin{array}{c}\text { Directed } \\
\text { Attention }\end{array}$ & $\begin{array}{c}\text { Overall } \\
\text { MALS }\end{array}$ \\
\hline MUET & 0.134 & -0.136 & -0.308 & 0.507 & -0.170 & 0.346 \\
\hline
\end{tabular}


Table 3. Spearman correlations between the overall MALS and its subscales

\begin{tabular}{|c|c|c|c|c|c|}
\hline $\begin{array}{c}\text { Spearman's Rho / Correlation } \\
\text { Coefficient }\end{array}$ & Problem Solving & $\begin{array}{c}\text { Planning and } \\
\text { Evaluation }\end{array}$ & $\begin{array}{c}\text { Mental } \\
\text { Translation }\end{array}$ & $\begin{array}{c}\text { Person } \\
\text { Knowledge }\end{array}$ & $\begin{array}{c}\text { Directed } \\
\text { Attention }\end{array}$ \\
\hline Overall MALS & 0.467 & 0.317 & -0.374 & 0.643 & 0.552 \\
\hline
\end{tabular}

In between overall MALS and its subscale, person knowledge shows the highest significant correlation of 0.643. This indicates that students with higher MALS score exhibited person knowledge the strongest compared to other subscales. The second highest correlation is directed attention, followed by planning and evaluation with 0.552 and 0.317 coefficient, respectively. Whereas there is a negative relationship of -0.374 between overall MALS and mental translation strategy where students with higher MALS score demonstrated this strategy the least.

\subsubsection{Data Triangulation}

The idea of MALS was quite new to them. Nonetheless, some of the practicing strategies that they mentioned, without realizing, are also related to subscales in MALS. When asked about their strategies before and while answering MUET listening, most of the responses encompass strategies such as checking the question paper, reading the question carefully, highlighting keywords, jotting down notes, and staying focus throughout the exam. This in line with the overall significant relationship between MALS and MUET. Despite that, due to the time limitation, sometimes it was difficult for them to think of a strategy. The test happened so quickly that they barely have time to recheck the answers. For them, listening test is only involved listening to audio and wait for the right answer to come up.

From the quantitative result, we can see that person knowledge not only shows a significant relationship to MUET result but also the overall MALS. Person knowledge represents listeners' perceptions concerning the difficulty presented by listening and their self-efficacy in listening to English as a second language [25]. Students who are confident about their listening activity tend to show a positive relationship to the listening test. Most of the students who are interviewed perceived that listening is less difficult compared to writing or reading. Listening can be difficult but circumstantial such as when the audio is not working, or the speaker speaks with heavy accents. Compared to listening, reading and writing tests in MUET are more difficult. Writing test requires the usage of low frequency word, thus challenging the students' vocabulary ability. Subsequently, the passages in reading test often contain dense information and demand many different strategies for comprehension.

The second highest significant relationship to overall MALS is directed attention. Directed attention involves students' ability to direct their attention to a subject matter [25]. Based on the responses, students focused on each word to get the answer while listening, tried to not get sleepy and frequently reminded themselves to stay focus. In a non-assessment setting, they put away all the distractions, such as handphone.

Additionally, results show that mental translation has a significant negative relationship with the MUET result. A number of respondents said they were unable to translate due to the time limitation. Students became confused if they translate during the test. They usually ignored the few words and try to make sense of the whole sentence.

\section{Discussion}

Findings show that there was a significant relationship between MALS and students' listening achievement. This is in line with the study conducted among a group of ESL learners from China studying in Singapore [31], Iranian university students of different majors [32] and Iranian EFL freshman university students [33]. Additionally, a study investigates the effects of metacognitive strategy training on lecture listening comprehension abilities to undergraduate students in one of Malaysia's public universities which shows that students who frequently use metacognitive strategies when listening to lectures in English scored higher in the listening test [18].

One of the subscales, person knowledge is positively significant to the MUET marks. Some study shows different prominent awareness of metacognitive strategies such as problem solving, planning and evaluation, mental translation strategies [32], and directed attention and problem solving [34].

Meanwhile, mental translation is negatively significant to listening achievement. This is in line with the explanation where it says that mental translation is an inefficient approach to listening comprehension and must be avoided avoid it if they want to become skilled listeners $[25,36]$, especially to beginner level listeners as they often feel required to use these strategies [35].

\section{Conclusions}

The findings of this study can be impactful towards students to be able to self-direct and self-reflect their efforts to improve their listening process. Just like building confidence in speaking skill by judging their competence, students can also evaluate their listening to improve their listening achievement in MUET. Furthermore, instead of only using MUET test specification to teach the listening skill, metacognitive instruction intervention could be applied in the tasks as it 
is shown to have a positive effect [37].

Listening comprehension should be viewed in a more principled manner rather than focusing on the outcome's achievement which may happen in MUET listening practices. Both learners and teachers should be aware that there is a process in listening comprehension just like other language skills [24]. They should have a clear insight of the development in listening practice and how metacognitive awareness can be used to manage efforts in listening activities [24,25].

Listening skill is crucial for students' academic success in university academic setting. The finding concerning metacognitive awareness among pre-university students is also significant to prepare them for their degree study [18]. It is important for students to enhance their listening skill for them to comprehend lectures in English as they may be unaware of strategies that could assist them $[18,39]$.

\section{REFERENCES}

[1] Feyten, C. M. (1991). The power of listening ability: An overlooked dimension in language acquisition. The modern language journal, 75(2), 173-180.

[2] Vandergrift, L. (2004). Listening to learn or learning to listen? Annual Review of Applied Linguistics, 24, 3-25.

[3] Mendelsohn, D. (2002). The lecture buddy project: An experiment in EAP listening comprehension. TESL Canada Journal, 20(1), 64-73.

[4] Zarrabi, F. (2016). The Impact of Listening Strategy Training on the Meta-Cognitive Listening Strategies Awareness of Different Learner Types. English Language Teaching, 9(5), 154-165.

[5] Rost, M. (2002). Teaching and Researching Listening. London, UK: Longman.

[6] Vandergrift, L., \& Tafaghodtari, H.M. (2010). Teaching L2 students how to listen does make a difference: An empirical study. Language Learning, 60, 470-497.

[7] Renandya, W. A., \& Farrell, T.S.C. (2011). "Teacher, the tape is too fast”: Extensive listening in ELT. ELT Journal 65: 52-59.

[8] Takei, A. (2002). What should be identified about listening? In A. Takei (Ed.), Consideration of listening in English: inquiring scientifically listening comprehension and instruction. Tokyo: Kagensha

[9] Nair, Suchithra \& Li Koo, Yew \& A. Bakar, Kesuma. (2014). Exploring the Listening Processes of Pre-university ESL Students. Procedia - Social and Behavioral Sciences. 118. 475-482. 10.1016/j.sbspro.2014.02.065.

[10] Khatijah Mohd. Tahir \& Gurnam Kaur Sidh. (2004). Assessing the listening performance component in the MUET in Ganakuman Subramaniam \& Shah Mizan Ismail (Ed.). Oracy in Focus (pp. 64 -75), Sasbadi Sdn. Bhd., Petaling Jaya.
[11] Online available: https://www.nst.com.my/news/nation/201 8/03/341993/muet-receives-cambridge-recognition-spreadwings-abroad-nsttv

[12] Rethinasamy, S., \& Chuah, K. M. (2011). The Malaysian University English Test (MUET) and its use for placement purposes: A predictive validity study. Electronic journal of foreign language teaching, 8(2), 234-245.

[13] Allen, S. H. L., \& Lee, E. W. (2017). Involvement of higher order thinking skills within a preparatory course for the Malaysian University English Test. The English Teacher, 18.

[14] Sulaiman, S., Abd, N. S., Rahim, R., Majid, A. A., \& Ibrahim, A. (2017). Listening Skills Strategies (PISA) Used in MUET: A Preliminary Study. International Journal of Asian Social Science, 7(10), 846-854

[15] Online available: http://portal.mpm.edu.my/documents/101 56/487e7320-4bdf-4bd1-8a77-33c82af188d6

[16] Online available: http://portal.mpm.edu.my/documents/101 56/89c75a23-b7a8-4a16-bade-a42436199c6e

[17] Vandergrift, L. \& Goh, C. (2012). Teaching and learning second language listening: Metacognition in action. New York: Routledge.

[18] Selamat, S., \& Sidhu, G. K. (2011). Student perceptions of metacognitive strategy use in lecture listening comprehension. Language Education in Asia, 2(2), 185-198.

[19] Nelson, T. O. (1996). Consciousness and metacognition.American Psychologist, 51, 102-116.

[20] Rahimi, M., \& Katal, M. (2012). Metacognitive listening strategies awareness in learning English as a foreign language: A comparison between university and high-school students. Procedia Social and Behavioural Sciences, 31, 82-89

[21] Wenden, A. (1998). Metacognitive knowledge and language learning. Applied Linguistics, 19, 515-537. Wigfield, A., \& Eccles, J. (2000). Expectancy-value theory of achievement motivation. Contemporary Educational Psychology, 25, 6881.

[22] Birjandi, P., Mirhassani, A. and Abbasian, G. (2006) Setting-based metacognitive strategy use. .Journal of Faculty of Letters and Humanities, 49(198), 39-87. Available online: www.sid.ir.

[23] Flavell, J. H. (1976). Metacognitive aspects of problem solving. In L. B. Resnick (Ed.), The nature of intelligence (pp. 231-235). Hillsdale, NJ: Lawrence Erlbaum.

[24] Vandergrift, L. \& Goh, C. (2012). Teaching and learning second language listening: Metacognition in action. New York: Routledge.

[25] Vandergrift, L., Goh, C., Mareschal, C., \& Tafaghodtari, M. H. (2006). The metacognitive awareness listening questionnaire (MALQ): Development and validation. Language Learning, 56, 431-462.

[26] Goh, C. (1997). Metacognitive awareness and second language listeners. ELT journal, 51(4), 361-369.

[27] Vandergrift, L. (2004). Listening to learn or learning to listen? Annual Review of Applied Linguistics, 24, 3-25. 
[28] Morse, J.M (2003). Principles of mixed methods and multimethod research design. In: Tashakkori, A., Teddie, C. (eds.) Handbook of Mixed Methods in Social \& Behavioral Research, pp. 189-208. Sage, Thousand Oaks

[29] Johnson, R.B., Onwuegbuzie, A.J., Turner, L.A.: Toward a definition of mixed methods research. J. Mix. Methods Res. 1(2), 112-133 (2007).https://doi.org/10.1177/15586898062 98224

[30] Tashakkori, A., Teddie, C. (2010b): The Sage Handbook of Mixed Methods in Social \& Behavioral Research, 2nd edn. Sage, Thousand Oaks

[31] Goh, C. (1997). Metacognitive awareness and second language listeners. ELT journal, 51(4), 361-369.

[32] Rahimi, M., \& Katal, M. (2012). Metacognitive strategies awareness and success in learning English as a foreign language: an overview. Procedia-Social and Behavioral Sciences, 31, 73-81.

[33] Shirani Bidabadi, F., \& Yamat, H. (2010). The Relationship between listening strategies used by Iranian EFL freshman university students and their listening proficiency levels. English Language Teaching, 4, 26-32.
[34] Goh, C. C., \& Hu, G. (2013). Exploring the relationship between metacognitive awareness and listening performance with questionnaire data. Language Awareness, 23(3), 255-274. http://dx.doi.org/10.1080/09658416.2013.769558

[35] Eastman, J. K. (1991). Learning to listen and comprehend: The beginning stages. System, 19, 179-187.

[36] Vandergrift, L. (2003). Orchestrating strategy use: Toward a model of the skilled second language listener. Language learning, 53(3), 463-496.

[37] Aguilera Escobar, G., Illesca Moya, C., Montecinos Negrete, C., Sandoval Sepúlveda, V., Navarro Martínez, C., \& Whipple Duprat, K. (2016). Metacognitive listening strategies: exploring the effects of implicit metacognitive instruction on intermediate second.

[38] Farquhar C, Protein and DNA Music, Online available from http://www.hrpub.org

[39] Selamat, S., \& Sidhu, G. K. (2013). Enhancing listening comprehension: The role of metacognitive strategy instruction (MetSI). Procedia-Social and Behavioral Sciences, 90, 421-430. 